\title{
A Study on the Comprehensive Reform of Art Education in Henan Non - governmental Institutions of Higher Learning in the Context of "One Belt One Road"
}

\author{
Hongjian Tang \\ Zhengzhou University of Industrial Technology, Zhengzhou, Henan, 450000
}

Keywords: One Belt One Road, Private Education, Art Education, Teaching Reform

\begin{abstract}
In September and October 2013, Chinese President Xi Jinping, during his visit to Central Asia and Southeast Asian countries, has put forward a major initiative to build the "Silk Road Economic Zone" and "21st Century Maritime Silk Road", which has received great attention from the international community. As of the end of 2015, China and "One Belt One Road" related countries trade volume accounts for about a quarter of total imports and exports, investment in the construction of more than 50 overseas economic and trade cooperation zone, contracted projects exceeded 3,000. In 2015, China's enterprises on the "One Belt One Road" related to 49 countries for direct investment, investment increased by $18.2 \%$ year on year. In 2015, China to undertake "One Belt One Road" related national service outsourcing contract amount of 17.83 billion US dollars, the implementation of the amount of 12.15 billion US dollars, up respectively $42.6 \%$ and $23.4 \%$.
\end{abstract}

\section{Introduction}

The Status Quo of Art Education in Non - governmental Colleges in Henan Province under the Background of "One Belt One Road"

Basic Situation of Art Education in Non - governmental Institutions of Higher Learning in Henan Province

Basic situation of private colleges and universities in Henan province

According to the University of Education published in June 2016, the number of universities in Henan Province, a total of 129 colleges and universities in Henan Province, undergraduate colleges and universities in Henan Province accounted for 30.91\% of colleges and universities, Henan Province, colleges and universities in Henan Province Compared with 27.03\%. Henan Province private higher education is an important part of higher education in Henan Province.

The Current Situation of Art Education in Non - governmental Institutions of Higher Learning in Henan Province

At present, 27 colleges and universities in Henan Province, colleges and universities set up an independent art college, including 11 colleges and universities at the same time set up a public art teaching department (public art education center) for the school to carry out various arts education. 12 colleges and universities set up a public art teaching department. 1 colleges and universities set up art teaching and research section.

Overall, private colleges and universities in Henan Province focus on art education, while carrying out the art of professional education at the same time, for the other professional students through the public arts teaching department to open vocational classes elective popular arts education. 


\section{The Problems of Art Education in Non - governmental Institutions of Higher Learning in Henan Province}

According to the Ministry of Education, "School Art Education Work Rules" (Ministry of Education Order No. 13), "National Higher Education Public Art Course Guidance Program" and other documents, the province's private colleges and universities have set up to set up the relevant art education institutions. But by the funds, teachers and the development of the concept of restrictions, especially private colleges, not the establishment of relevant institutions responsible for the overall management of the public art teaching institutions, can not form a good artistic education atmosphere.

The source of funds for private colleges and universities students account for an important proportion of tuition fees, public art education, itself is not an independent college, do not have the qualifications, their sources of funds, funding is limited. Public education courses only theoretical education, can not be courageously ahead of practice, leading to the decline in the quality of teaching, not to the original purpose of public art education.

Private colleges and universities lack of teachers, which is a common problem for all private colleges and universities. Public art teaching department teachers do not have independent teachers, which is bound to affect the promotion of art education.

The province of art education mode, is still to spoon-fed, indoctrination-based. Classroom generally used PPT presentation by the class, students with passive acceptance of knowledge-based. Art education should be different from traditional education. Art education itself exists in the student's interest, hobby choice of learning. So, how to break through, change passive acceptance for active learning, is an important aspect of this article.

The rapid development of regional economy, bringing new production mode. These new things, the need for more talent to promote the development of new industries, such as the rapid development of new media in recent years, the Internet +, "One Belt One Road". While some colleges and universities talent training program similar to the age of flowers. How can these programs be trained to meet the requirements of today's times?

\section{"One Belt One Road" under the background of the development of art education in the face of the challenges}

"One Belt One Road" to connect China, North Korea and other countries. These countries are different customs, religious beliefs are different, such as: Indian traditional dance, grasping food. Regional cultural differences require colleges and universities to break through the limitations of personnel training, cultivate an international field of comprehensive talents, so as to better serve "One Belt One Road" great strategy to further realize the great rejuvenation of the Chinese nation.

At present, the national colleges and universities in the art of recruitment are divided into art and cultural performance test. Compared to other candidates, art candidates after art test, the relative requirements of cultural performance will be reduced.

From the college entrance examination scores can be seen, the college entrance examination is a total score of 750 points, art candidates only need to reach 268 points can enter the undergraduate institutions. In this supply and demand environment requirements, their cultural literacy requirements do not need too high, can design a perfect product to meet customer needs.

In the "One Belt One Road" environment, Asia, Europe and Africa countries and regions of the regional economic culture and art constantly collide, blend, which is the nation, culture, integration, but also a way of human culture and art advanced.

With the gradual advancement of economic globalization, the global trend of expansion of American film and television, the influence of traditional Chinese culture is gradually weakening. In this context, we want to make Chinese culture break through the Western culture to block out, affect the world, the achievements of the Chinese dream. But in what form to let the Chinese culture to go out, we need to solve the problem. 
The airport economic zone, expand art education, with the emerging technology, build China's feelings, promote the traditional culture and art education, to create high-quality compound talents

"One Belt One Road" under the strategy of dozens of countries, hundreds of ethnic groups, mutual influence, common integration, development. In this environment, to maintain the influence of Chinese culture, promote other countries and regions of economic and cultural development, must rely on people's influence. And high-quality, high-quality college students is the main force of cultural integration.

"One Belt One Road" strategy is the international exchange and cooperation, the artist's words and deeds have influenced foreign recognition of China, so the students need a certain cultural quality.

Cultural performance can show its overall comprehensive ability. If there is no sufficient knowledge of the reserves can not survive abroad, talk about the spread of Chinese culture. Therefore, to enhance the entry threshold of art students, is the first basis for order training, but also better adapt to the requirements of the environment.

"One Belt One Road" under the strategy of dozens of countries, hundreds of ethnic groups, mutual influence and common development. And our students can not be one person proficient in multiple languages, understand the national customs, then how to solve this problem?

That is to strengthen international exchanges, the implementation of order-style personnel training. Colleges and universities to strengthen international exchanges, through direct cooperation between colleges and universities to achieve graduation and go abroad to synchronize employment. In recent years, Zhengzhou Institute of Industrial Applied Technology and Thailand Boren University, Malaysia Southern University and other foreign universities in-depth cooperation, through the school cooperation, directly to the international school-enterprise cooperation, direct delivery of talent to foreign enterprises. During the course of cooperation, the school will carry out specialized language training courses and customs training courses, the shortest time for students to understand the familiar customs of Malaysia, pay attention to matters. In this mode of education, Zhengzhou Industrial Application Technology College graduates, graduation has been independent in Malaysia survival and development, innovation and entrepreneurship.

Henan is the birthplace of Chinese civilization, culture, population province. Henan University of art education to deepen the Chinese civilization, Zhengzhou Institute of Industrial Applied Technology in the art of education based on the Yellow Emperor culture, and constantly deepen the connotation of innovative clothing design, produced a typical Chinese style of clothing, these dress by foreign friends preferences, This is the charm of traditional Chinese culture.

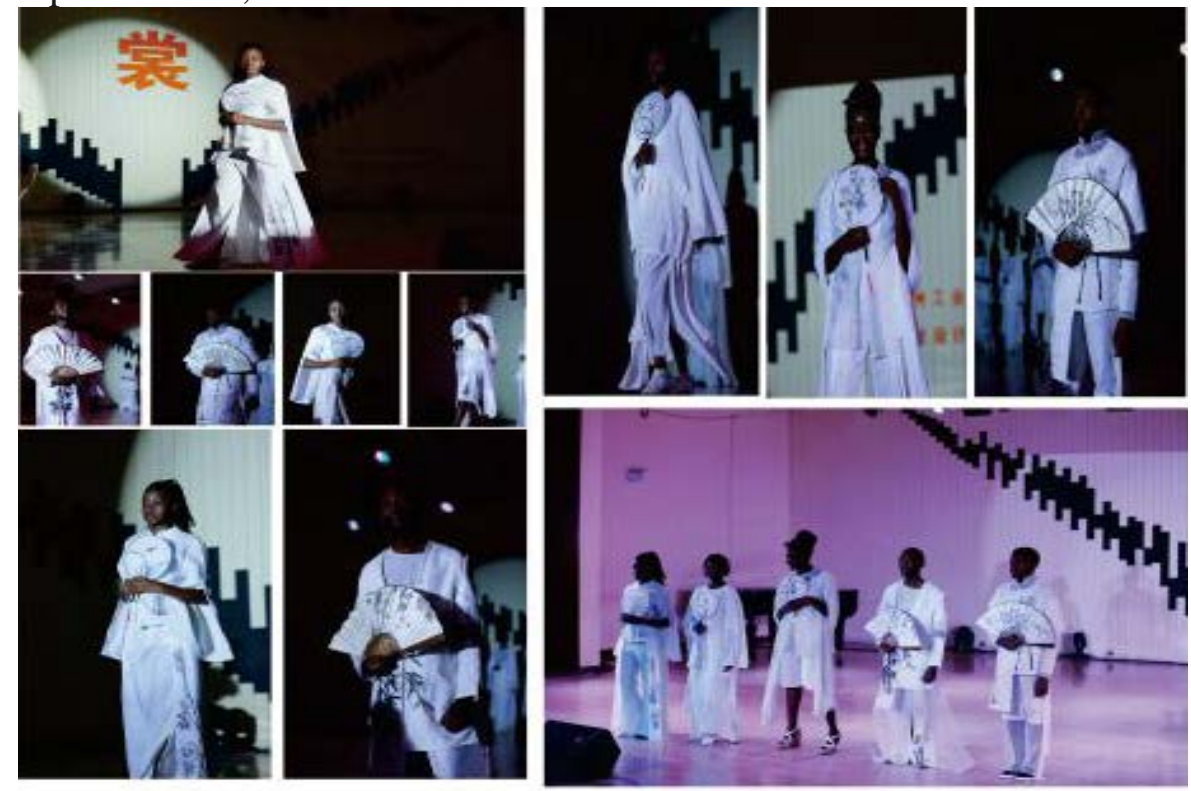

Figure 1 Foreign friends dressed in Chinese costumes 
Art education must deepen the traditional culture, cultivate talent with Chinese culture and art temperament. In the "One Belt One Road" environment, with the output of talent, and gradually export the Chinese culture, the impact of "a

With all the way "economic zone, to achieve cultural and artistic assimilation, in order to achieve the great rejuvenation of the Chinese nation.

\section{Conclusion}

Based on the airport economic zone, to promote the traditional culture and art of education, to create high-quality compound talents with new technologies to open up a new model of art education, strengthen international exchanges, through order-based talent training model to achieve one-on-one output. At the same time, to develop a new platform, leveraging "One Belt One Road" to strengthen the traditional Chinese culture and art education, and gradually talent output, and ultimately achieve cultural output, to achieve the Chinese dream. This paper puts forward some strategies to solve some problems in the new era of art education in colleges and universities, hoping to provide some useful reference for the reform of art education in colleges and universities in Henan province.

\section{References}

[1] Chen Lin. 2013 China Education Information Development Perspective [J]. Education Research, 2014, 35 (6): 136-141.

[2] DIAMOND I R, GRANT R C, FELDMAN B M, et al. Defining consensus: a systematic review recommends for procedural criteria for reporting of Delphi studies [J]. Journal of clinical epidemiology, 2014, 67 (4): 401-409.

[3] Zhong Guangrui, Zheng Chunyan.Application of mobile learning in curriculum teaching in colleges and universities [J]. Journal of Jiaying University, 2014, 32 (3): 82-86.

[4] Luo Jie. Information technology to promote learning change - from classroom learning to virtual learning, mobile learning to pan-learning [J]. China Audio-Visual Education, 2014 (1): 15-21.

[5] Zhou Zhenhua. Emotional Computing: New Practice of Artificial Intelligence Industry Concurrently on the Enlightenment to the Development of Shanxi's Wisdom [J]. Economic Issues, 2016 (6): 60-63.

[6] Li Ke. Artificial intelligence of the new breakthrough and the robot era of vocational education [J]. Wuxi Vocational and Technical College, 2016, 15 (4): 20-22.

[7] Zhang Xiaofang, Zhang Lei. On machine learning and its application in education [J]. Information and Computer (Theoretical Edition), 2015, 24: 074.

[8] Wei Xuefeng. Problem solving and cognitive simulation: taking math problems as an example [M]. Beijing: China Social Science Press, 2016.

[9] Gao Yonghong, Gao Hengyu. Talking about the relationship between education and technology in educational technology research - Taking the application of artificial intelligence in education field [J]. Global Market Information Guide, 2014 (40): 72-74.

[10] LUO Jiu-tong, SUN Meng, GU Xiao-qing.Improvement of MOOC in the Perspective of Mixed Learning: A Case Study of SPOC [J]. Modern Educational Technology, 2014, 24 (7): 18-25.

[11] YANG Wei-feng, XIA Xiao-hong.Multi-learning model of innovation culture construction in internet era [J]. China Geological Education, 2012, 30 (2).

[12] Yang Junfeng, Huang Ronghuai, Liu Bin. Review of foreign learning space research [J]. China Audio-Visual Education, 2013 (6): 15-20.

[23] Wu Xiao, Yang Cheng.Study on the Deep Learning Model of College Students in Mobile 
Environment [J]. China Information Technology Education, 2014 (20): 10-11.

[14] Fu Qian, Wang Mingxiao.When the trainees encounter STEAM education [J]. Modern Educational Technology, 2014 (10): 37-42.

[15] Li Wenmin. To enhance the level of teachers' information, to promote the development of higher vocational education - to participate in the 2014 National Vocational College Information Technology Competition [J]. Science and Technology, 2014 (24): 211-211. 